\title{
Paediatric cardiac surgery in Serbia - who are we closer to?
}

\author{
M Stajevic \\ From 23rd World Congress of the World Society of Cardio-Thoracic Surgeons \\ Split, Croatia. 12-15 September 2013
}

\section{Background}

Department for Congenital Heart Surgery at the Mother and Child Health Institute of Serbia dates from 1982.

\section{Methods}

The team consists of 2 surgeons, one resident, three anaesthesiologists and 2 intensivists. The number of operated cases at the Mother and Child Health Institute of Serbia is between 130 and 160 per year.

\section{Results}

In 2003. four projects commenced: the arterial switch operation, Norwood I, redo surgery and valvular surgery. For arterial switch, after initial successes, came a series of deaths resulting in a high mortality of over $40 \%$. The analysis of the risk factors showed that beside surgical misses, the reasons were various levels of motivation and dedication between different members of the surgical team. Only after reorganization the results changed dramatically: the mortality rate for ASO is now under $8 \%$. The crucial identified risk factor was long anaesthesia induction and management of the immediate postoperative care. The results of treatment of HLHS with an overall mortality above $75 \%$ are still distant from the current standards. Inadequate preoperative management and late referrals are the main reasons for mortality. Children with valvular anomalies are dominantly treated with valve replacements. The univentricular heart patients have longer postoperative recovery, mortality varies between $12 \%$ and $16 \%$. The results of the routine paediatric cardiac surgery are consistent with results of the major cited literature data.

ECMO and heart transplant are not available in our country. The lack of financial and donor support and the

Correspondence: mstajevic@yahoo.com

Pediatric Cardiac Surgery, Mother and Child Health Institute of Serbia, Belgrade, Serbia potentially low number of patients gravitating towards our institution question the cost benefit ratio.

\section{Conclusions}

Compared to the surrounding countries, the provided services offered at our hospital can be regarded as cheaper, available and up to the standards of contemporary mid developed European countries.

Published: 11 September 2013

doi:10.1186/1749-8090-8-S1-P160

Cite this article as: Stajevic: Paediatric cardiac surgery in Serbia - who are we closer to? Journal of Cardiothoracic Surgery 2013 8(Suppl 1):P160.
Submit your next manuscript to BioMed Central and take full advantage of:

- Convenient online submission

- Thorough peer review

- No space constraints or color figure charges

- Immediate publication on acceptance

- Inclusion in PubMed, CAS, Scopus and Google Scholar

- Research which is freely available for redistribution

Submit your manuscript at www.biomedcentral.com/submit
() Biomed Central
C Biomed Central 